University of South Florida

DIGITAL COMMONS

Digital Commons @ University of

@ UNIVERSITY OF SOUTH FLORIDA

South Florida

Reports

Tampa Bay Area Study Group Project

1999

\title{
The rehabilitation of the Tampa Bay Estuary, Florida, USA, as an example of successful integrated coastal management
}

R. R. Lewis

P. A. Clark

W. K. Fehring

H. S. Greening

R. O. Johansson

See next page for additional authors

Follow this and additional works at: https://digitalcommons.usf.edu/basgp_report

Part of the Environmental Indicators and Impact Assessment Commons

\section{Scholar Commons Citation}

Lewis, R. R.; Clark, P. A.; Fehring, W. K.; Greening, H. S.; Johansson, R. O.; and Paul, R. T., "The rehabilitation of the Tampa Bay Estuary, Florida, USA, as an example of successful integrated coastal management" (1999). Reports. 134.

https://digitalcommons.usf.edu/basgp_report/134

This Statistical Report is brought to you for free and open access by the Tampa Bay Area Study Group Project at Digital Commons @ University of South Florida. It has been accepted for inclusion in Reports by an authorized administrator of Digital Commons @ University of South Florida. For more information, please contact digitalcommons@usf.edu. 
Authors

R. R. Lewis, P. A. Clark, W. K. Fehring, H. S. Greening, R. O. Johansson, and R. T. Paul 


\title{
The Rehabilitation of the Tampa Bay Estuary, Florida, USA, as an Example of Successful Integrated Coastal Management
}

\author{
R. R. LEWIS III+*, P. A. CLARK + W. K. FEHRINGS, H. S. GREENING †T, R. O. JOHANSSON \\ R. T. PAULSS \\ Thewis Environmental Services, Inc., P.O. Box 20005, Tampa, FL 33622-0005, USA \\ †Tampa Baylatch, Ine., 840I Ninth Street North, Suite 230-B, St. Petershurg, FL 33702, USA \\ \$URS Grioner. 7650 West Courtney Camphell Causewey, Tampa, FL 33607-1462, USA \\ TTampa Bay Estuary Progran, 1/17th Avente South. St. Petersburg, FL 33701, USA \\ 4 Bay Study Group, Department of Sanitary Siewers. City of Tampa. 700 Marime Boulevard. Tampa, HI. 3360.5, USA \\ \$SNational Audubon Society, 410 Ware Boulevard, Suite 500. Tampa, FL, 33619, USA
}

The Tampa Bay Ecosystem is located in the state of Fiorida, USA. The $6739 \mathrm{~km}^{2}$ ecosystem has undergone major changes duc to coastal development, including dredging for maintenance and expansion of the $10 \mathrm{kh}$ largest pert in the USA. Approximately $44 \%$ of the historic emergent coastal wetlands and $81 \%$ of the historic submergent seakrass meadows had been lost through 1981. Declines in commercial and recreational fisheries harvests and coastal wildife populations followed similar trends in declines. Beginning threc decades ago, an informal Integrated Coastal Management (ICM) program initiated by citizen groups has progressed to a formal ICM program that has initiated restoration of the ecosystem and management through a unique multi-county umbrella organization, the Tampa Bay Fistuary Program. () 1999 Elsevier Science Ltd. All rights reserved

\section{History}

The Tumpa Bay ecosystem includes $967 \mathrm{~km}^{2}$ of primarily unvegetated csiuarine waters with an average depth of $3.5 \mathrm{~m}, 72 \mathrm{~km}^{2}$ emergent coastal wetlands and a $5700 \mathrm{~km}^{2}$ watershed for a total area of $6739 \mathrm{~km}^{2}$ (Fig. 1) (Lewis and Estevez, 1988; Tampa Bay National Estuary Program, 1996). Approximately $10 \%$ of the $967 \mathrm{~km}^{2}$ of open water area $\left(101 \mathrm{~km}^{2}\right)$ have shallow $(<2 \mathrm{~m})$ shelves vegetated with seagrasses (Johansson and Ries, 1997).

The primary emergent coastal vegetation consists of mangrove forests with three species of trecs, Rhizophora

\footnotetext{
*Corresponding author. Tel.: 1.1-813-889-9684: fax: + 3-813-881. i 5\$6; c-mail: lewenvsvesstaol com
}

mangle L. Avicenmia gemminats (L.) L. and Layzurataria raemosa Gaerin. f., with about $20 \%$ of the total area dominated by silt marshes consisting mostly of smooth cordgrass (Spartina alterniflort Loisel.) and needlerush (Juncus romorianzs Scheele) (Lewis and Estevez, 1988). Seagrass neadows are dominaled by Thalassia testulinum Konig and Hedothle wightii Ascherson (Lcwis et at., 1985).

The watershed supports a population (ca. 1995) of 2 million within the cities of Tampa, St. Petcrsburg, Clearwater, Bradenton and surrounding strburban communities (Fig. 1). The first modern recognition of the bay's decline came from the US Public Health Service (Galtstoff, 1954), citing pollution from municipal discharges with nonexistent or inatequate treatment, industrial wastes from phosphate mines, citrus cannerics, and other sources as major contributors. (ialtstof (1954) stated that "Tampiz Bay is grossly polluted, and bathing waters in Clearwater Harbor and St. Joseph Sound have been affected adverseiy.

\section{Problem Identification}

The first suggestion that controls on eutrophication and dredging impacts were necded came in 1969. The Federal Water Pollution Control Adninistration (1969) recommended a water quality management plan and waste abatement program to control odour and other pollution symptoms in Hilisborough Bay, and a master plan for dredging and filling the bay. Also in the early 1970 s, a citizens group called Save Our Bay began to push for a halt to uncontrolled dredging and sewage disposal in the bay. At the same time, the federal govcrnment was shifting more attention to environmenta? 
Volume 37/Numbers \& 12/August December 1998

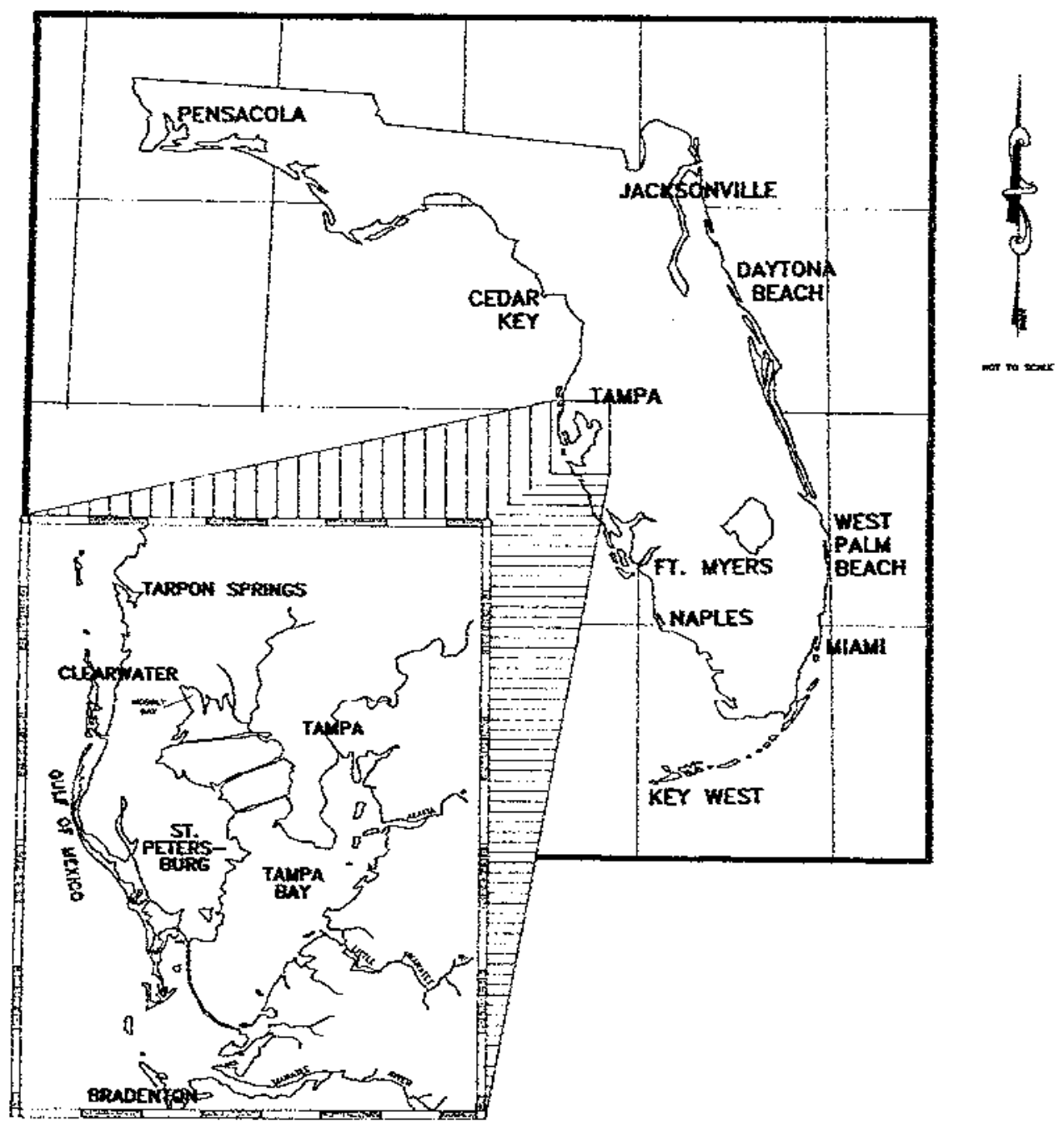

\section{LOCATION MAP}

lijo. I Map of Florida showing the kotion of Tampa baty.

necds with the establishment of the US Environmental Protection Agency (EPA) On of the major accomplishments of the EPA in its carly years was providing federal grants to upgrade sewage treatment plants.

As a result of the federal report and of citizens call for action, one of those grants was awarded to the city of Tampin which had for decades piped faw or barely treated scwage into Tampa Bay. The sewage was believed to be a major reason why many portions of the bay experienced continuous blue-green algae blooms and were badly polhuted (Johansson and Lewis, 1992). This grant enabled Tampa to install an advanced wastewater treatment system (i.e. nutrient removal) at the plant in $197 \%$, one of the first of its kind in the country. The lechnological improvements reduced the flow of nitrogen by an estimated $90 \%$ below untreated eftiuent levels, an achievement that is recognized today as a comerstone in the bay's recovery. Subsequent state Icgislation, currently requires all sewarge treatment facilities discharging to the bay to meet advanced treatment standards, with a total nitrogen concentration limit of $3 \mathrm{mg} / \mathrm{l}$. The city of St. Petersburg chose another route to address its scwage disposal problems when it pionecred the first large-scale wastewater reuse program in the state, resulting in greally reduced discharge of nitrogen to the bay.

In the late 1960s, the Environmental Protection Commission of Hillsborough County (EPC) was established. Over the years, EPC has provided a comprehensive recoid of tong-term water quality trends in the bay, critical for tracking and documenting fong-term water yuality conditions and the bay's progressive re- 
covery. EPC was one of the first agencies to identify sewage treatment problems in the bay, and its wetland protection rules arc among the strictest in the state.

The estuary has been a major seaport for over $100 \mathrm{yr}$. Currently the port is rated as the tenth largest in the United States in overall tonnage (52 million tons/year). The largest exports are phosphate rock and fertilizer products, while the largest inports are petroleum and coal. The modifications of the estuary to facilitate coastal development, including port construction, have resulted in the excavation or filling of $44 \%$ of the emergent coastal wellands (i.e. tidal marshes and mangrove forests originally estimated as covering $108 \mathrm{~km}^{2}$ ) (Lewis, 1977).

Historical (pro-1930) scagrass meadows in Tampa Bay are believed to have covered $310 \mathrm{~km}^{2}$ of the shallow bay botton based upon historical maps and patterns of modern distribution. Interpretation of vertical aerial photographs from the 1950 s and 1982 yielded about 165 and $88 \mathrm{~km}^{2}$ of seagrass, respectively, suggesting a $72 \%$ loss from the earlicst estimate and a $47 \%$ loss since 1900 (Lewis, 1977; Lcwis at al., 1985).

\section{Problem Resolution}

An informal Integrated Coastal Management program, derived mainly from eitizen action groups, began with the first Earth Day in 1969. Dredging of coastal wetlands to create waterfront housing was toppod in 1975. Water quality targets were initially technology based, and later ttater quality hased. This means that regulatory criteria to establish when violations occurred started by defining what types of sewage treatment (i.c., primary, secondary) should be applied (technology based). I ater receiving water quality parameters were used (water quality based). Eventually, resource based criteria utilizing seagrass distribution becine the standard (Lewis, 1991). Bay-wide seagrass mapping has been conducted by the South-west Florida Water Management District every $2 \mathrm{yr}_{\mathrm{r}}$ since 1988. Results from this study show that the trend of seagrass loss has been reversect. The 1994 cover was estimated at near $108 \mathrm{~km}^{2}$, indicating an increase of almost $23 \%$ since 1982 (Figs. 2 and $3 i-c)$. The seagrass expansion started in response to water quality improvements which occurred more than a two decades ago and which in turn followed a large roluction in nitrogen loading from primarily domestic and industrial point-sources (Johansson and Lewis, 1992). Although this nutrient reduction occurred almost two decades ago, the decline in macroulgae and microalgae blooms and an increase in water transparency did not become apparent for almost $5 \mathrm{yr}$.

The Tampa Bay National Estuary program has adopied goals to protect existing Tampa Bay seagrass meadows and to restore, over the long term, 5000 ha of additional seagrass primarily through the control of nitrogen loading to the bay. Tampa Bay seagrass meadows in areas popular to hoaters are impacted by propeller scarring. Studies have been fundod to deter- mine the extent of propeller impacts and to evaluate management options for the protection of the inpacted areas.

The programme to restore lost mangrove and tidal marsit wetlands began atmost 30 yr ago witl experimental work that firmly established the most appropriate and cost effective methodologies for restoring these habitats within damaged bay environments (see summirics in Lewis, 1990; (rewz and Lewis, 1991). The key criteria being the understanding of the bay's unique pattern of secondary succession in intertidal plant communities whercby smooth cordgrass colonizes recovery shallow intertidal arcas formerly covered with mangroves and is later replaced by mangroves through compctition (Lewis, 1982). In addition, the correct construction of tidal platforms at the correct tilal dattun clevation for marshes and mangroves was found to be the most important criterias for successful construction of tidal wetlands (Crewz, and Lewis, 1991). Data collection on the rate of natural colonization by fish of newly created tidal wellands in Tampa Bay also indieated that fish poputations essentially istentical in both species conposition and tolal numbers to controt wetland sites recruited within 5 yr of their construction (Lewis, 1992; Whitman and Gilmore, 1993). These scientific studies when applied to the isste of restoration allowed bay managers to proced quickly to designing large-scate restoration prograns without delays to justify whether they would 'work' to restore functional habitats.

A bay-wisie wethand and coastal upland restoration program has been developed and adopted for the bay (Lcwis Environmental Services, Inc., and Coastal Environmental, like, 1996) and is being implemented with costs per hectare of USD $\$ 62500$ (excluding the cost of the land) using public agency staff and equipment to the largest extent possible. This is one-half of the normal commercial cost of such efforts. These cosis are broken down into $18 \%$ for preconstruction activitics (design, pernitting) and $75 \%$ for construction and $7 \%$ for monitoring. These costs are slightly more than those reported by King and Bohlen (1994) in a national study, but may reflect variations in local costs. To date 0.45 $\mathrm{km}^{2}$ of wethands have been restored by the Surface Water Improvement and Management (SWIM) Program of the Somh-west Florida Water Management District.

\section{Discussion}

The struggle to protect and manage the natural resources of Tampa Biy has evolved in less than $30 \mathrm{yr}$ from a grass-roots citizens effort to a complex, nultilayered network involving three countics, a dozen cities, a variety of regional and federal agencies and numerous citizens and spccial interest groups. Tampa Bay's approach to Integrated Cotstal Mamagement (GCM) originated as a 'bottom tp approach' with strong local 


\section{Seagrass Decline and Recovery Tampa Bay, Forida, USA}

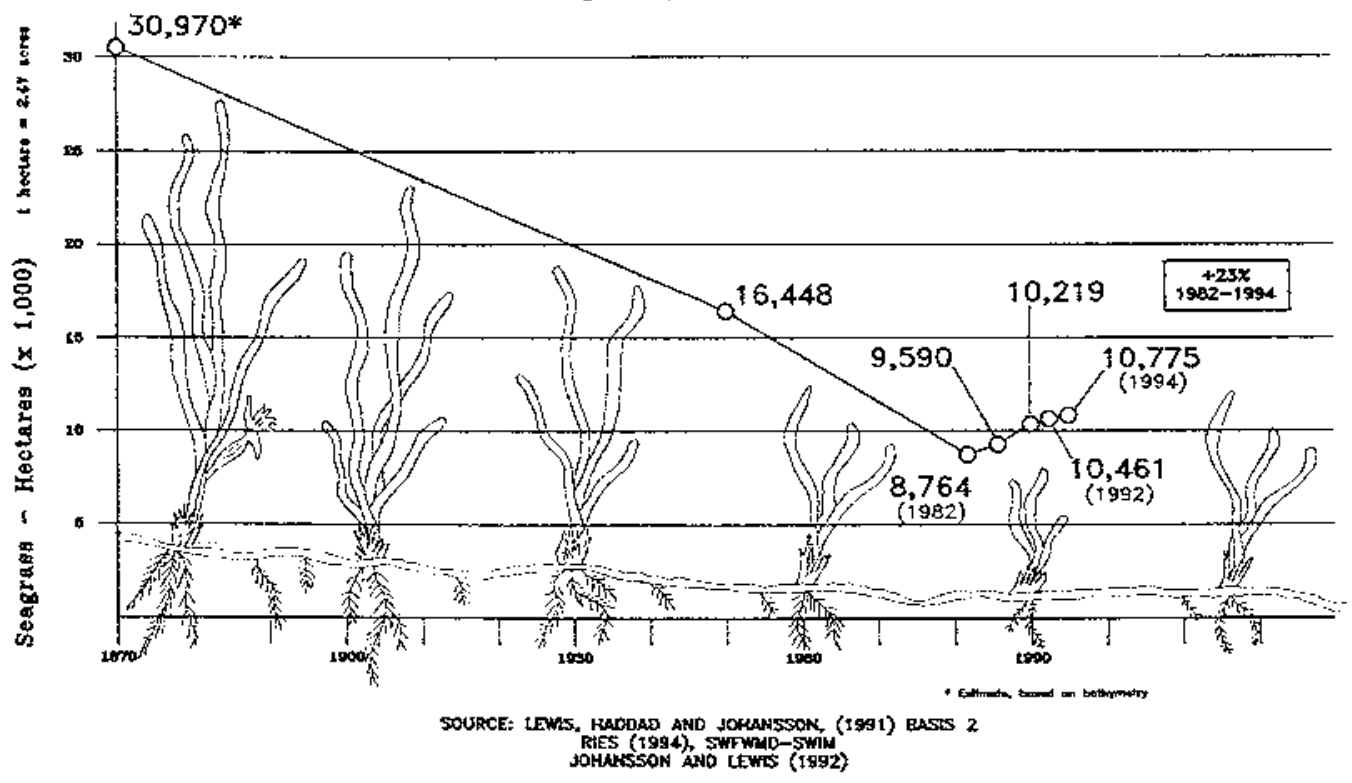

Fig. 2 Graph showing the measured areal extent of seagrass meadows in Tanipa Bay over time.

citizen impetus. ( itizen involvement and concern remain inportant driving factors through local government cornmitment to reach long-term goals for bay restoration developed with state and federal programs. A key lesson Iearnt here is that ICM programs are more likely to succed if you start with strong local support rather than simply try to impose a program on a local community from some senion statewide agency (i.e. the topdown approach). This is also referred to as the tcommunty based approach.

Following 6 yr of scientific research and community dialogue, the Tampa Bay National Estuary Program (TBNEP), a partnership that includes the EPA, Florida Department of Environmental Protection, South-west Florida Water Management District, Hillsborough, Pinellas and Manatec counties, the cities of St. Petersburg, Clearwater and Tampa, the Florida Game and Freshwater Fish Commission. US Amy Corps of Enginecrs. Tampil Bay Regional Council, the Environmental Protection Commission of Hillsborough County, and the Florida Marine Research Institute, adopted a long-term stralcgy to protect and restore Tampa Bay's critical living resoutces. As noted before, this resource based strategy emphasizes using actual measured quantitative changes, such as areal extent of scagrass, or populations of birds, as the criteria for success or fitilure. Goitls of the binding agreenent to implentent the sirategy include the following:

\section{Habitat:}

- Recover an additional 5000 ha of seagrass baywide.
- Restore a minimum of 40 ha of tidal stream habitat every 5 yr while preserving existing marsh and mangrove habitat.

- Establish minimum seasonal freshwater fows to the bay and its tributaries to support fisheries habitat. Water uzulity:

- Prevent increases, over 1992.1994 levels, of nitrogen entering the bay to cncourage seagrass recovery.

- Implement actions to reduce toxic materials in impacted bay sediments.

- Implement actions to reduce bacterial contamination in areas which fail to meet bealth standards for swimming and fishing.

Fish and wildife:

- Protect and enhance fish and wildlife populations and improve enforcement of environnental regulations. Spilt prevention and response:

- Install a vessel tracking system to reduce the chance of collisions and spills.

Dredging and dredged material matergement:

- Develop a long-term coordinated dredging and dredged material management plan for Tampa Bay. Pablic cilucation and involvement:

- Educate the public about bay issues and progress, and enlist them in bay protection.

The signatories to the agreement have agreed to collectively achicve these goals and to submit action plans detailing bow they will meet their specific responsibilities. The agreement includes a specific time frame for accomplishing each of the goals for bay improvenent, to be updated every $5 \mathrm{yr}$, and a strong baywide moni- 


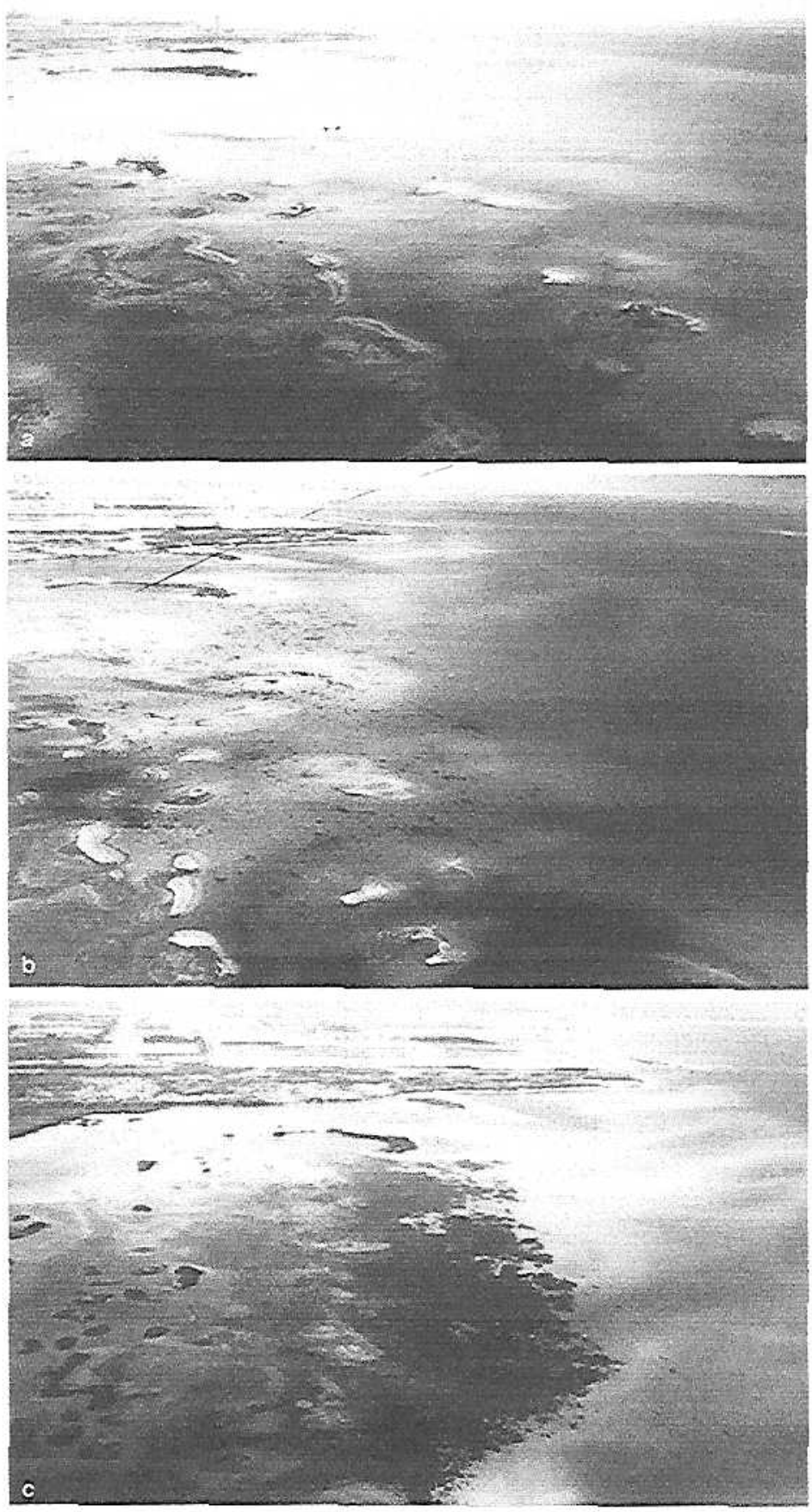

Fig. 3 (a) Oblique colour aerial photograph looking south along Tampa Bay's eastern shoreline showing large accumulations of macroalgae (dark signatures in foreground). Seagrasses are absent in this March 1986 photograph. (b) Same area as Fig. 3a. photograph taken in 1990. Some macroalgac in forcground but dark spots are newly colonized seagrass patches of shoalgrass, Halodule wrightiii. (c) Same area as Fig. 3a, photograph taken in 1996. Shoalgrass meadows have coalesced to form the dark continuous seagrass meadow in the centre. Lighter signature to the left in the photograph are beds of the annual seagrass Ruppia maritima. 
toring program to measure progress (or lack of) toward gouls. The program leaders are the Tampa Bay Estuary Proguam, a local aurency derived from the federatly funded TBNEP.

Strong local direction and committment coupled with good science and significant support from state and federal programs has resulted in an ICM approach for Tampa Bay focused on agreed-upon measurable goals for bay restoration and the committment to attain then. Citizen watch-dogs are still present and are still necded to continue to monitor kxal agency responsiveness, but the future of the bay's natural and human resources appears bright.

(renvz, D. and Lewis, R. R. (1991) Evaluation of historicat] attempts to establish energent vegetation in marinc welkands in Florida. Florida Seagram College TechnicaI Paper No. 60. Gainesville, ïlorikit, USA.

bederall Water Pollution (ontrol Administration (1969) Problems and mithigement of walce paility in Hillsborcough Bay, Florida. Washington, DC. CUSA

Gastoff. P. S. (1954) (iulf of Mexice. Its origins, wathers and marine

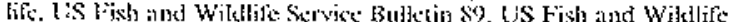
Service. Washington. DC' IISA.

Johinsson. J. O. R. ant l.ewis. R. R. (1992) Recent improvements of water quality and biologicat! indicators in Hiltshorough Bay, a highly impacted stuldivision of Tampa Bay, Fosida. WSA. Internationat Conterence on Marine Coastal Eutrophication. Bologna. Italy, March 1990. In Sicnce of the Totat Ensiroment, Sitpptement 1992, pp. 1199 1215. Elsevier. Amsicrtam, 11991215.

Jotanaion. J. O. R. and Ries, T. (1997) Seagrass in Tampa Bay: historic irends and tature expectations. In Procerdingx. Tampo Bat Area Scienific Information Sumpesiam 3, ed. S. F. Treal, pp. 139

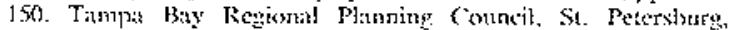
Florida, l'SA.

King, D. M.. and Bolrlen, (. C. (1994) Making sense of welland restoration costs, (juiversity of Mirryland Center for Environmentat atmd Estuarine Sudies, Solmmons, Maryland, USA.
Lewis, R. R. (1977) Inpacts of dredging in the Tampa Bay estuary.

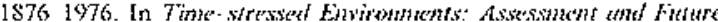
Actions, ed. E. L. Druit, sp. 3t 55. Coastal Socicty, Arlington, Virginia, USA

Lewis, R. R. (19S2) (irtation ath Restoration of ("otstat Plomt Communitis, CRC Ptess, Bowai Rattom, Florida, iJSA.

I cwis. R. R. (1990) Creation and restoration of coastal plain wetlands in Ilorida. In W'ctlunts ("reation and Restoration: the Status of the Srience, eds. J. A. Kusier and M. E. Kentula, pp. 73 tol. Isiand Press, Washington, DC, LSA.

Lewis, R. R. (1991) Resoulce based water quality management in

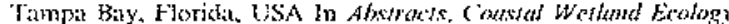
ond Manumom Swmusim, eds. J. I. Mecder and R. F. Turner. no paging. New Orkans, Louisiana, IJSA.

Lewis, R. R. (1992) Coastal habital restoration as a fishery mamalge-

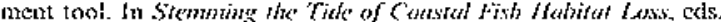
R. Ft. Stroud, pp. 169 173. Procecdings of a Symposizm on Conservation of Coastal Fish f fabitat. Billimore, Md. 7 ) March 1991. National Coalition for Marine Conservation, Inc. Situnnah. Goorgia, USA.

Lewis, R. R., Durnko, M. J., Mother, M. D. ank Phillips, R. C. (1985) Seagrass meadows of Tampa Bay. In Protedings of the Tampa Buy Ares Siterific Information Simposinam eds. S. F. Treitl. J. L.

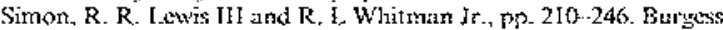
Pubiishing Co., Minneapolis, Minnesota. USA.

Lewis, R. R, and Estevez, E. D. (1985) The Ecology of Tampa Bay, Florista: an Esturtinc Profile, US Fish and Wildtife Service Biologieal Report No. 85 (7.iS). National Wellands Research Center, Slidell. Lomisiant. USA.

Lewis Environmental Services, Ine. and Coastal Environmenta]

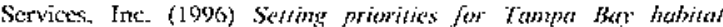
protection and restortion: restoring the batance. Tech. Pub. Pp. 09 95. Tampa Bay Nationat Estuary Program, Tampa, Florida. USA

Tampa Biy National Estuary Program. (1996) (harting the coursc for Tampi Bily. Tampat Bay National [istatry Program and ₹S Favironmental Prolection Agency Region IV, St Petersburg Foridir and Atlanti, Georgia, USA.

Whitman, R. L. Jr. and Gilmore, R. G. 3r. (1993) Comparative evalution of fisteries compunity structure ad habilat refationships in mitural and created salimassh ecosystems. Surface Water Improvement and Management d'rogram, Southwest florida Watcr Manasement District, Brooksville, Jiloridat, USA. 